\title{
Response of onion crop to bulb set size and planting date under mulching in dry Mediterranean environment
}

\author{
Ibrahim MUBARAK ${ }^{1,2}$
}

Received June 10, 2018; accepted June 14, 2021. Delo je prispelo 10. junija 2018, sprejeto 14. junija 2021

\begin{abstract}
Response of onion crop to bulb set size and planting date under mulching in dry Mediterranean environment

Abstract: The present pot experiment under open field conditions was conducted to evaluate the response of onion crop to bulb set size and planting date using mulching. Two different sizes of onion sets at planting (large (6-10 g) and small (2-6 g)) and three different planting dates (February, March, and April) with two soil coverings (with and without straw mulching) were tested. Treatments were replicated three times. Onion was not exposed to any drought stress during the course of the experiment.

Results indicated that the larger bulb sets which were planted earlier under mulching, maximised the total bulb yield (Yield, $44.0 \mathrm{t} \mathrm{ha}^{-1}$ ), water use efficiency (WUE, $8.37 \mathrm{~kg}$ $\mathrm{m}^{-3}$ ), and irrigation water use efficiency (IWUE, $9.57 \mathrm{~kg} \mathrm{~m}^{-3}$ ). Moreover, findings revealed that onion crop appreciably respond to smaller bulb sets when they were planted earlier under mulching. Onion bulb responses were predicted to be linearly increased with the earliness in planting date, with an obvious better preference under mulching and heavier bulb sets. Hence, adopting early planting date with mulching is suggested for sustainable crop production and for enhancing water use efficiency in dry Mediterranean area.

Key words: total bulb yield; bulb shape index; water use efficiency; irrigation water use efficiency; trend analysis
\end{abstract}

Odziv pridelka čebule na velikost čebulčkov, datuma sadnje in mulčenja $\mathrm{v}$ suhem sredozemskem okolju

Izvleček: Lončni poskus na prostem je bil izveden za vrednotenje odziva pridelka čebule v odvisnosti od velikosti čebulčkov in datuma sadnje $\mathrm{z}$ uporabo mulčenja. Za sadnjo sta bili uporabljeni dve velikosti čebulčkov, velika (6-10 g) in mala (2-6 g), tri datumi sadnje (februar, marec, in april) in dva načina prekrivanja tal ( $\mathrm{z}$ in brez zastrtja s slamo). Obravnavanja so bila s tremi ponovitvami. $V$ času poskusa čebula ni bila izpostavljena sušnemu stresu.

Rezultati so pokazali, da je zgodnja sadnja večjih čebulčkov dala ob prekrivanju tal večji celokupni pridelek čebul $\left(44,0 \mathrm{t} \mathrm{ha}^{-1}\right)$, imela je boljšo učinkovitost izabe vode (WUE; $8,37 \mathrm{~kg} \mathrm{~m}^{-3}$ ), in večjo učinkovitost namakanja (IWUE; 9,57 $\mathrm{kg} \mathrm{m}^{-3}$ ). Izkazalo se je tudi, da je sadnja drobnejših čebulčkov dala dober pridelek, če so bili posajeni zgodaj in, če so bila tla prekrita. Napovedan odziv pridelka čebule se je linearno povečeval z zgodnostjo sadnje, predvsem pa z velikostjo čebulčkov in prekrivanjem tal. Zaradi naštetega priporočamo za trajnostno pridelavo čebule $\mathrm{v}$ suhem sredozemskem območju zgodnjo sadnjo in prekrivanje tal $\mathrm{z}$ mulčenjem.

Ključne besede: celokupen pridelek čebule; velikostni indeks čebul; učinkovitost izrabe vode; učinkovitost namakanja; analiza trendov

1 Department of Agriculture, Atomic Energy Commission of Syria, P.O. Box 6091, Damascus, Syria

2 Corresponding author, e-mail: ascientific2@aec.org.sy 


\section{INTRODUCTION}

Onion (Allium cepa L.) is one of the most important crops worldwide. The ecological conditions such as temperature and photoperiod largely affect its growth and production. Also, the cultural practices such as planting date, size of onion bulb sets at planting, and irrigation water availability have an impact on crop production (Brewster, 2008; Khokhar, 2014; Mubarak and Hamdan, 2018a). Onion crop thrives best when temperatures are cool during early development period and then warmer and sunny during maturity. Hence, planting date has a profound impact on onion crop growth and development. Early planting date tends to have a longer onion growing season before bulb initiation ensuring larger plants. However, large plants are more likely to become sensitive to the cold stimulus resulting in bolting (formation of seed stalk followed by flowering), which represents a highly unfavourable feature for onion bulb production. Large plants are also related with split bulbs. However, late-date-planted onions start forming bulbs before reaching satisfactory plant growth to support the final size of bulbs. This would produce very small bulbs, and therefore, decreasing the bulb yield (Brewster, 2008; Rohini and Paramaguru, 2016).

Onion crop has a shallow rooting system, and therefore, it is considered as a sensitive crop to water stress than other crops with deeper roots. Water use efficiency (WUE) is usually used to recognize the cultural practices by which the yield per unit water can be optimized. In the dry regions where water resources are limited as in the dry Mediterranean region, improving water use efficiency and crop yield represents a main challenge for agricultural water management. In this context, soil mulching could be considered as a key water-saving technique that would help in meeting both water scarcity and sustainable crop production. Mulching can decrease the loss of soil water through evaporation and maintains soil water content, and thereby reducing irrigation water requirements, promoting rooting system development, and increasing crop growth, development and yield (Vavrina and Roka, 2000; Gimenez et al., 2002; Hamma, 2013; Mutetwa and Mtaita, 2014; Mubarak and Hamdan, 2018b; Mubarak, 2020)

There have been several studies conducted on the effects of onion bulb sets at planting on both seed production (Singh and Sachan, 1999; Abedin et al., 1999; Khokhar et al., 2001; Ashrafuzzaman et al., 2009), and the total onion bulb yield at harvest (Addai et al., 2014; Addai and Anning, 2015). They reported that large onion sets produced the greatest vegetative development and total bulb yield. In other word, the larger the onion bulb sets, the higher the total bulb yield.

In the dry Mediterranean area, bulb sets as directly planted in the soil is a common practice, probably the simplest method employed to establish onion in the field as compared with planting using the seeds. Farmers plant onion bulb sets in the spring and harvest in the summer. The production period between April and August is characterized by no rainfall (Ragab and Prudhomme, 2002; Turner, 2004). Moreover, the Mediterranean climate is extremely variable with hot and dry summer, and cold and wet to dry winters. The Middle East and North Africa are dry areas, with only $1 \%$ of the renewable water resources (Joffre and Rambal, 2001; Turner, 2004; Ceccarelli et al., 2007). The increasing climatic change have intensified the vulnerability to drought (Giorgi and Lionello, 2008; Somot et al., 2008; FAO, 2011; Polade et al., 2014). An increase by 1.25$2.5^{\circ} \mathrm{C}$ in temperature is predicted in winter, and the precipitation between October and March will decrease by $10-15 \%$ in the southern Mediterranean countries (Ragab and Prudhomme, 2002).

As the crop production is already limited by the water availability and local climate, moving towards feasible tools (such as using mulching) and agronomic practices (such as changing planting date) adapted to climate change is urgently needed for improving irrigation and cultivation period of crop (FAO, 2011; Khokhar, 2014; Zinkernagel et al., 2015). In this context, and responding to the Sustainable Development Goals (SDGs) putted forward by United Nations to adapt to climate change and to sustain agricultural production, the present work aimed to evaluate the combined effects of different planting date, bulb set size, and mulching on onion crop production. The obtained outcomes may encourage the introduction of alternative and more effective practices, to stimulate onion farmers in the region to adopt using straw mulching in their fields and to select bulb sets of uniform and large sizes for planting. This would sustain onion crop production with efficient water use in the dry Mediterranean area.

\section{MATERIALS AND METHODS}

A pot experiment was conducted under open field conditions at the Agricultural Experimental Station, near Damascus, Syria $\left(33^{\circ} 20^{\prime} \mathrm{N}, 36^{\circ} 26^{\prime} \mathrm{E}\right.$, altitude $600 \mathrm{~m}$ ), for different planting seasons in 2017. The site is located within a dry Mediterranean area, in which the long-period average of the total annual rainfall is about $120 \mathrm{~mm}$. Some climatic data for the studied site 
collected during the growing seasons was fairly close to those averaged over the last 16 years (from 2000 to 2016) as can be shown in Table 1. For this reason, testing different planting seasons during one year (2017) seemed somewhat adequate.

The soil is classified as a clay loam, containing on average $29.5 \%$ clay, $42.7 \%$ silt, and $27.8 \%$ sand. Both volumetric soil water contents at permanent wilting point $(P W P)$ and field capacity $(F C)$ are 0.18 and $0.36 \mathrm{~m}^{3} \mathrm{~m}^{-3}$, respectively. The chemical and physical soil properties are: $\mathrm{pH} 8.0$; ECe $0.34 \mathrm{ds}^{-1}$; organic matter $1.20 \%$; available P $5.7 \mathrm{ppm} ; \mathrm{NO}_{3}{ }^{-} 28.3 \mathrm{ppm} ; \mathrm{NH}_{4}{ }^{+}$ $12.6 \mathrm{ppm}$.

Pots with dimensions of $25 \times 30 \mathrm{~cm}$ and containing $8 \mathrm{~kg}$ of soil were used in the experiment. Three bulb sets of onion (Allium cepa 'Selmouni Red') were planted in each pot. The pots were set outdoors under natural climatic conditions. Plants were thinned after germination to two bulbs per pot, getting a plant density of about 400000 plants ha-1.

Three different planting dates separated with 28 days were tested: PD1 (on February $8^{\text {th }}$ ), PD2 (on March $8^{\text {th }}$ ), and PD3 (on April $5^{\text {th }}$ ). At each planting season, the experiment was laid out following a $2 \times 3$ factorial experiment arranged in a randomized complete block design with two sizes of onion sets and two types of soil covering, with three replicates. The sizes of onion sets composed of large sets (OS1: 6-10 g), and small sets (OS2: 2-6 g). The soil covering comprised two distinct types. The first one (M1) was with straw mulching using $40 \mathrm{~g} \mathrm{pot}^{-1}$ (about $8 \mathrm{tha}^{-1}$ ); and the second one (M2) was without mulching. In all pots, plants received $100 \%$ of the crop evapotranspiration; and the root zone was replenished to the field capacity. Irrigation water was applied three times/week. Each experiment was started on the planting day with a wet soil at field capacity as measured by pot's mass. The pots were weighed before and after each irrigation event. The water amount depleted $(\mathrm{mm})$ between two successive irrigation events (ETc) was regulated by weight and estimated using (Eq.

$$
E T c=\frac{M t_{1}-M t_{1}}{\rho_{w} \times A}
$$

1) as:

where $M t_{1}$ : the mass of the pot $(\mathrm{kg})$ after irrigation (the soil water content in the pot was at the field capacity); $M t_{2}$ : the mass of the pot $(\mathrm{kg})$ just before the next irrigation event; $\rho_{w}$ : the water density $\left(\mathrm{g} \mathrm{cm}^{-3}\right)$; and $A$ : the pot soil surface area $\left(\mathrm{m}^{2}\right)$. The daily crop evapotranspiration $\left(\mathrm{mm} \mathrm{day} \mathrm{d}^{-1}\right)$ was estimated by dividing the ETc calculated using Eq. (1) by the number of days between two successive irrigations. The seasonal crop evapotranspiration was the summation of the daily ETc, which represented the total crop water requirements during a growing season.

For each planting season, phosphorous and potassium were applied as basal dose at planting day; but nitrogen fertilizer was divided into two equally split applications added during early vegetative stage. Irrigation was stopped when more than $50 \%$ of leaf-head was hung and turned yellow. The onions were lifted to field cure about two weeks after. After the leaves were completely dried, they were cut leaving about $2.0 \mathrm{~cm}$ tops above the bulb. The length (BL), diameter (BD), and mass of both matured onion bulbs from each pot were measured. The shape index (Sh I) was calculated as the ratio of bulb length to diameter (BL/BD). The total bulb yield (Yield, $t \mathrm{ha}^{-1}$ ) was estimated. Water use efficiency (WUE, $\mathrm{kg} \mathrm{m}^{-3}$ ) was estimated by dividing yield by the seasonal crop evapotranspiration. Irrigation wa-

Table 1: Some climatic data for the experimental station as averaged over the last 16 years (from 2000 to 2016), and those measured during the year 2017

\begin{tabular}{lllllllll}
\hline Year & Variable & Feb. & Mar. & Apr. & May & Jun. & Jul. & Aug. \\
\hline \multirow{4}{*}{$2000-2016$} & $\mathrm{~T}_{\min }\left({ }^{\circ} \mathrm{C}\right)$ & 4.0 & 6.8 & 10.1 & 14.1 & 17.6 & 19.3 & 20.4 \\
\multirow{2}{*}{ average } & $\mathrm{T}_{\max }\left({ }^{\circ} \mathrm{C}\right)$ & 15.7 & 20.6 & 25.3 & 30.4 & 35.0 & 37.4 & 37.4 \\
& $\mathrm{~T}_{\text {average }}\left({ }^{\circ} \mathrm{C}\right)$ & 10.6 & 15.0 & 18.1 & 23.6 & 27.7 & 29.4 & 28.7 \\
& $\mathrm{RH}(\%)$ & 75.0 & 64.1 & 60.9 & 56.5 & 56.3 & 60.7 & 60.2 \\
& Rainfall $(\mathrm{mm})$ & 31.0 & 31.6 & 5.9 & 4.2 & 0.0 & 0.0 & 0.0 \\
\hline \multirow{4}{*}{2017} & $\mathrm{~T}_{\min }\left({ }^{\circ} \mathrm{C}\right)$ & 4.0 & 6.2 & 9.7 & 14.4 & 17.2 & 20.6 & 20.0 \\
& $\mathrm{~T}_{\max }\left({ }^{\circ} \mathrm{C}\right)$ & 14.7 & 18.7 & 26.2 & 31.6 & 35.7 & 40.6 & 38.5 \\
& $\mathrm{~T}_{\text {average }}\left({ }^{\circ} \mathrm{C}\right)$ & 9.1 & 14.0 & 19.2 & 24.9 & 28.4 & 31.1 & 28.9 \\
& $\mathrm{RH}(\%)$ & 69.3 & 74.4 & 63.1 & 57.9 & 56.3 & 56.0 & 59.0 \\
& Rainfall $(\mathrm{mm})$ & 11.6 & 42.6 & 0.0 & 0.0 & 0.0 & 0.0 & 0.0 \\
\hline
\end{tabular}

$\mathrm{T}_{\min }:$ minimum temperature, $\mathrm{T}_{\max }$ : maximum temperature, $\mathrm{T}_{\text {average }}$ : average temperature, $\mathrm{RH}$ : relative air humidity 
ter use efficiency (IWUE, $\mathrm{kg} \mathrm{m}^{-3}$ ) was also calculated by dividing yield by the irrigation water amount.

The two-way analysis of variance (ANOVA) was conducted using the DSAASTAT add-in (Onofri, 2007), for each planting season. A combined analysis of data over seasons was carried out to examine the interaction between planting season and the studied treatments (Gomez and Gomez, 1984). Mean comparison was made only for data after achieving the combined analysis using the LSD test at the $1 \%$ level. Trend analysis (regression analysis) was also performed.

\section{RESULTS AND DISCUSSION}

Table 2 summarizes the effects of tested factors (planting date, onion set size, and soil cover system) on the measured traits of onion crop (BD, Sh I, Yield, WUE, and IWUE).

\subsection{BULB SHAPE INDICATORS}

Two indicators were used in this study to represent the shape of onion bulbs: bulb diameter (BD) and the shape index (Sh I). Both indicators were found to be highly affected by the main effects of all studied factors according to the ANOVA (Table 2). Since no significant interaction was observed, the data under each factor were pooled over the other factors for mean comparison purposes (Table 3).

Results indicated onion sets planted early in February (PD1) produced bulbs with larger diameter of $3.82 \mathrm{~cm}$. Then, BD significantly decreased by 26 and $39 \%$ compared with those planted later in March (PD2) and April (PD3), respectively. With regard to onion set size, the heavier set (OS1) produced bulbs with diameter $30 \%$ larger than OS2. Moreover, onion sets grown under mulching produced bulbs with mean diameter significantly larger than those grown without mulching (Table 3).

Results showed that the minimum and maximum mean values of shape index (Sh I) were obtained from onion sets which were planted in PD1 and PD3 (or PD2), respectively. Also, using heavier onion sets (OS1) resulted in a decrease in Sh I by about $10 \%$ relative to lighter onion sets (OS2). When mulching was used, Sh I significantly decreased by $20 \%$ compared with nomulching conditions (Table 3 ). As the tested variety is an oval- to elongated-shape onion, the better the bulb shape for marketing purposes, the lower the shape index. Hence, the suggested agricultural practice to obtain better shape index is to plant onion sets early in February using mulching and larger onion sets. Similar results about the role of mulching in enhancing the bulb shape indicator were reported by Mubarak and Hamdan (2018b).

Table 2: Analysis of variance of the combined data of crop responses as affected by planting date, onion set size, and soil cover system (significance of F-test)

\begin{tabular}{|c|c|c|c|c|c|c|}
\hline Source of variance & $d f$ & $\mathrm{BD}$ & Sh I & Yield & WUE & IWUE \\
\hline Planting date (PD) & 2 & $* * *$ & $* * *$ & $* * *$ & $* * *$ & $* * *$ \\
\hline Rep. within PD & 6 & & & & & \\
\hline Onion set size (OS) & 1 & $* * *$ & $* * *$ & $* * *$ & $* * *$ & $* * *$ \\
\hline Soil cover system (M) & 1 & $* * *$ & $* * *$ & $* * *$ & $* * *$ & $* * *$ \\
\hline $\mathrm{PD} \times \mathrm{OS}$ & 2 & ns & ns & $* * *$ & $* * *$ & $* * *$ \\
\hline $\mathrm{PD} \times \mathrm{M}$ & 2 & ns & ns & ns & $* * *$ & $* * *$ \\
\hline $\mathrm{M} \times \mathrm{OS}$ & 1 & ns & ns & $* * *$ & $* * *$ & $* * *$ \\
\hline $\mathrm{PD} \times \mathrm{M} \times \mathrm{OS}$ & 2 & ns & ns & ns & ns & ns \\
\hline Pooled error & 18 & & & & & \\
\hline Total & 35 & & & & & \\
\hline CV (\%) & & 5.17 & 9.21 & 5.51 & 5.85 & 5.94 \\
\hline
\end{tabular}


Table 3: Mean comparisons of crop responses as influenced by planting date, soil cover system, and onion set size

\begin{tabular}{|c|c|c|c|c|c|}
\hline & $\mathrm{BD}(\mathrm{cm})$ & Sh I $\left(\mathrm{cm} \mathrm{cm}^{-1}\right)$ & Yield $\left(\mathrm{t} \mathrm{ha}^{-1}\right)$ & WUE $\left(\mathrm{kg} \mathrm{m}^{-3}\right)$ & IWUE $\left(\mathrm{kg} \mathrm{m}^{-3}\right)$ \\
\hline \multicolumn{6}{|l|}{ Planting date } \\
\hline PD1 (February) & $3.82 \mathrm{a}$ & $1.26 \mathrm{~b}$ & $30.77 \mathrm{a}$ & $5.08 \mathrm{a}$ & $5.73 \mathrm{a}$ \\
\hline PD2 (March) & $2.82 \mathrm{~b}$ & $1.64 \mathrm{a}$ & $25.99 \mathrm{~b}$ & $4.00 \mathrm{~b}$ & $4.08 \mathrm{~b}$ \\
\hline PD3 (April) & $2.33 \mathrm{c}$ & $1.64 \mathrm{a}$ & $20.02 \mathrm{c}$ & $2.78 \mathrm{c}$ & $2.78 \mathrm{c}$ \\
\hline$\underline{L S D}_{0.01}$ & 0.18 & 0.16 & 1.66 & 0.27 & 0.29 \\
\hline \multicolumn{6}{|l|}{ Onion set size } \\
\hline OS1 (6-10 g) & $3.36 \mathrm{a}$ & $1.43 \mathrm{~b}$ & $31.73 \mathrm{a}$ & $4.89 \mathrm{a}$ & $5.18 \mathrm{a}$ \\
\hline OS2 (2-6 g) & $2.62 \mathrm{~b}$ & $1.60 \mathrm{a}$ & $19.45 \mathrm{~b}$ & $3.02 \mathrm{~b}$ & $3.21 \mathrm{~b}$ \\
\hline $\mathrm{LSD}_{0.01}$ & 0.15 & 0.13 & 1.35 & 0.22 & 0.24 \\
\hline \multicolumn{6}{|l|}{ Soil cover system } \\
\hline M1 (with mulching) & $3.37 \mathrm{a}$ & $1.36 \mathrm{~b}$ & $31.16 \mathrm{a}$ & $5.46 \mathrm{a}$ & $5.83 \mathrm{a}$ \\
\hline M2 (without mulching) & $2.61 \mathrm{~b}$ & $1.67 \mathrm{a}$ & $20.03 b$ & $2.45 \mathrm{~b}$ & $2.56 \mathrm{~b}$ \\
\hline $\mathrm{LSD}_{0.01}$ & 0.15 & 0.13 & 1.35 & 0.22 & 0.24 \\
\hline \multicolumn{6}{|l|}{ Interactions } \\
\hline $\mathrm{PD} 1 \times \mathrm{OS} 1$ & $-^{\mathrm{y}}$ & $-^{y}$ & $37.89 \mathrm{a}$ & $6.23 \mathrm{a}$ & $7.02 \mathrm{a}$ \\
\hline $\mathrm{PD} 1 \times \mathrm{OS} 2$ & - & - & $23.64 \mathrm{c}$ & $3.93 c$ & $4.44 \mathrm{c}$ \\
\hline $\mathrm{PD} 2 \times \mathrm{OS} 1$ & - & - & $32.44 \mathrm{~b}$ & $4.98 \mathrm{~b}$ & $5.08 \mathrm{~b}$ \\
\hline $\mathrm{PD} 2 \times \mathrm{OS} 2$ & - & - & $19.54 \mathrm{~d}$ & $3.02 \mathrm{e}$ & $3.08 \mathrm{~d}$ \\
\hline $\mathrm{PD} 3 \times \mathrm{OS} 1$ & - & - & $24.87 \mathrm{c}$ & $3.45 \mathrm{~d}$ & $3.45 \mathrm{~d}$ \\
\hline $\mathrm{PD} 3 \times \mathrm{OS} 2$ & - & - & $15.17 \mathrm{e}$ & $2.12 \mathrm{f}$ & $2.12 \mathrm{e}$ \\
\hline$\underline{L S D}_{0.01}$ & 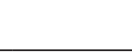 & & 2.34 & 0.38 & 0.41 \\
\hline $\mathrm{PD} 1 \times \mathrm{M} 1$ & $-^{y}$ & $-\mathrm{y}$ & $--^{y}$ & $6.94 \mathrm{a}$ & $7.93 \mathrm{a}$ \\
\hline $\mathrm{PD} 1 \times \mathrm{M} 2$ & - & - & - & $3.23 \mathrm{~d}$ & $3.53 c$ \\
\hline $\mathrm{PD} 2 \times \mathrm{M} 1$ & - & - & - & $5.52 \mathrm{~b}$ & $5.65 \mathrm{~b}$ \\
\hline $\mathrm{PD} 2 \times \mathrm{M} 2$ & - & - & - & $2.47 \mathrm{e}$ & $2.51 \mathrm{~d}$ \\
\hline $\mathrm{PD} 3 \times \mathrm{M} 1$ & - & - & - & $3.92 \mathrm{c}$ & $3.92 \mathrm{c}$ \\
\hline $\mathrm{PD} 3 \times \mathrm{M} 2$ & - & - & - & $1.65 \mathrm{f}$ & $1.65 \mathrm{e}$ \\
\hline $\mathrm{LSD}_{0.01}$ & & & & 0.38 & 0.41 \\
\hline $\mathrm{M} 1 \times \mathrm{OS} 1$ & $--^{y}$ & $--^{y}$ & $38.07 \mathrm{a}$ & $6.67 \mathrm{a}$ & $7.12 \mathrm{a}$ \\
\hline $\mathrm{M} 1 \times \mathrm{OS} 2$ & - & - & $24.24 \mathrm{~b}$ & $4.25 \mathrm{~b}$ & $4.55 \mathrm{~b}$ \\
\hline $\mathrm{M} 2 \times \mathrm{OS} 1$ & - & - & $25.40 \mathrm{~b}$ & $3.11 \mathrm{c}$ & $3.25 \mathrm{c}$ \\
\hline $\mathrm{M} 2 \times \mathrm{OS} 2$ & - & - & $14.65 \mathrm{c}$ & $1.79 \mathrm{~d}$ & $1.87 \mathrm{~d}$ \\
\hline $\mathrm{LSD}_{0.01}$ & & & 1.91 & 0.31 & 0.34 \\
\hline
\end{tabular}

y“-” = Interaction is not significant.

In each column and studied factor, means followed by different letters are significantly different according to LSD at $1 \%$ level. BD $=$ Bulb diameter, Sh I= shape index, Yield = total bulb yield, WUE = water use efficiency, and IWUE = irrigation water use efficiency

\subsection{TOTAL YIELD OF ONION BULBS (YIELD)}

The ANOVA revealed that Yield was significantly influenced by the main effects of all studied factors at the $1 \%$ level.

Results demonstrated that early planting date sig- nificantly enhanced the total yield of bulbs. An increase of $54 \%$ in yield was obtained when onion sets were planted in February compared with the current practice followed by farmers (in April) (Table 3). This could be due to the fact that onion sets which were planted in February were subjected to cool temperatures dur- 
ing the vegetative stage, favouring photosynthesis, and consequently enhancing crop production. In fact, onion is a vegetative overwintering stage in its life cycle, i.e., it thrives best when temperatures are cool during early growth stages (Brewster, 2008). Cool temperatures during the vegetative stages allow having vigorous growth that ensures increased photosynthetic capacity by onion leaves and ultimately attain the maximum bulb development. Similar results were also documented by Mohanty (2002), Hamma (2013), Rohini and Paramaguru (2016), and Mubarak (2020).

In addition, using larger onion sets resulted in a considerable increase in yield (about $63 \%$ ) compared with smaller onion sets. Several studies reported similar results that the large sets produce heavier bulbs than the small sets (Ansari et al., 2009; Addai et al., 2014; Addai and Anning, 2015).

A further significant increase of $56 \%$ in yield could be obtained under mulching relative to nonmulching conditions. The results are in accordance with similar findings previously reported (Vavrina and Roka, 2000; Igbadun et al., 2012; Hamma, 2013; Mutetwa and Mtaita, 2014; Mubarak and Hamdan, 2018b). In fact, mulch decreases evaporation from soil surface, providing more available water for plants (Igbadun et al., 2012). This could moderate the severity of wettingdrying cycle between irrigations, and therefore, yield could be improved (Vavrina and Roka, 2000; Gimenez et al., 2002; Mubarak and Hamdan, 2018b). Moreover, mulching could improve soil fertility and soil physical properties, and consequently, yield could be augmented under mulching (Khaledian et al., 2010; Khaledian et al., 2011).

On the other hand, the effect of planting date $x$ onion set size interaction on yield was also highly significant (Table 2). Trend analysis showed that yield was predicted to be increased linearly with the earliness of planting date, for each tested size of onion sets (Fig. 1A). The slope of representative line under OS1 is about 1.5 times greater than that under OS2. That is to say that yield increased with the earliness of planting date in a higher rate using larger onion sets than using smaller sets. This could explain the existence of the interaction between planting date and onion set size.

For presentation and discussion purposes, the responses of yield to different planting dates under both mulching and non-mulching conditions were demonstrated in Figure 1B. Trend analysis showed also the linear relationship between yield and planting date $(p \leq$ 0.01). Parallel representative lines confirmed the lack of interaction between planting date and soil cover system $(\mathrm{PD} \times \mathrm{M})$ as found by ANOVA (Table 2 ).

The interaction effect of soil cover system and onion set size $(\mathrm{M} \times \mathrm{OS})$ on yield was significant $(p \leq$ $0.001)$. The maximum yield was obtained using larger onion sets planted under mulching (38.07 $\left.\mathrm{t} \mathrm{ha}^{-1}\right)$; while the minimum one was obtained using smaller onion sets without mulching $\left(14.65 \mathrm{t} \mathrm{ha}^{-1}\right)$. Also, results indicated that using mulching enhanced the response of yield to smaller onion sets, with a significant increase of about $65 \%$ (Table 3 ).

Consequently, both experimental data and developed linear equations could be used for accurate yield prediction in order to sustain onion crop production under similar climatic conditions. For example, the recommended agricultural management to maximize yield is to plant larger onion sets early in February under mulching conditions. In such management, Yield could be attained about $44 \mathrm{t} \mathrm{ha}^{-1}$.

\subsection{WATER USE PARAMETERS}

The irrigation water applied to PD1, PD2, and PD3 were, 710, 800, and 910 under non-mulching conditions, and 460, 565, and $640 \mathrm{~mm}$ under mulching, respectively. Seasonal crop evapotranspiration (ETc), as calculated by Eq. (1), under non-mulching conditions were 775, 811, and $910 \mathrm{~mm}$, while under mulching were 525, 578, and $640 \mathrm{~mm}$, for PD1, PD2, and PD3, respectively. Both crop water use and irrigation water amount were considerably reduced when mulching was used. An important water portion of about $30 \%$ was saved under mulching relative to non-mulching conditions. Similar findings were also documented by Mubarak and Hamdan (2018b). Furthermore, early planting date resulted in significant decreases in both crop water consumption and irrigation water amount. These findings emphasize the importance of both early planting date and mulching in water resource management for irrigation purposes. The irrigation water saving due to both early planting and mulching could be utilized to irrigate additional cropped area.

The analysis of variance demonstrated that both WUE and IWUE were highly significantly affected by the main effects of the three tested factors. The two-factor interactions were also highly significant (Table 2).

Onion sets planted early in PD1 recorded maximum WUE and IWUE. After that, a gradual reduction in both efficiencies was recorded. Also, both WUE and IWUE were optimised when larger onion sets were used with an important increase of $62 \%$ relative to the use of smaller sets. In addition, when mulching was used, both WUE and IWUE were higher than those without mulching (Table 3).

Trend analysis showed that both WUE and IWUE 


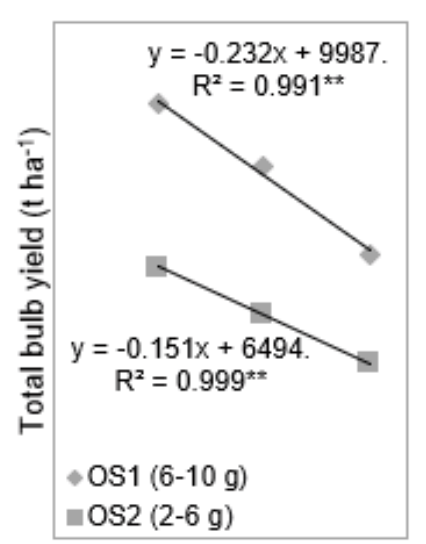

Planting date
A

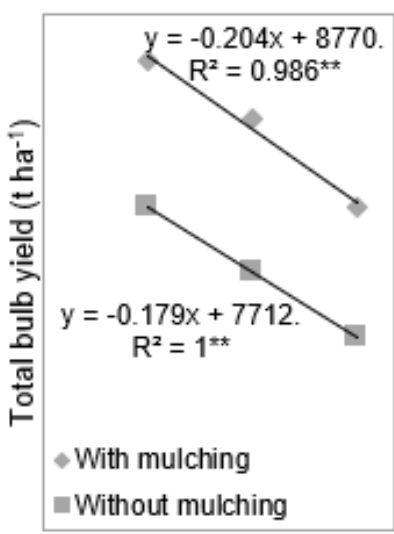

Planting date
B

Fig. 1: Response of total onion bulb yield to plant. date under (A) the two sizes of onion sets at planting, and (B) the two types of soil covering. Regression equations were fitted and coefficients of determination $\left(\mathrm{R}^{2}\right)$ were given. ${ }^{* *}=$ significant at $1 \%$ level

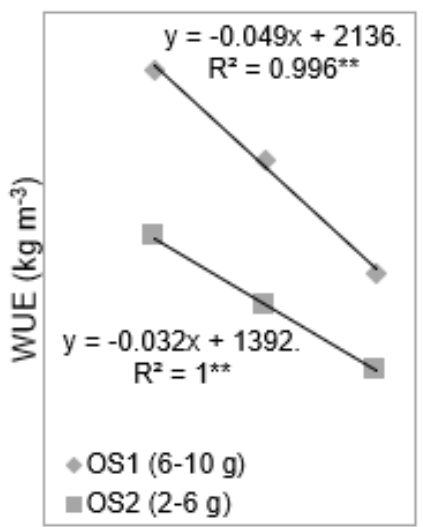

Planting date
A

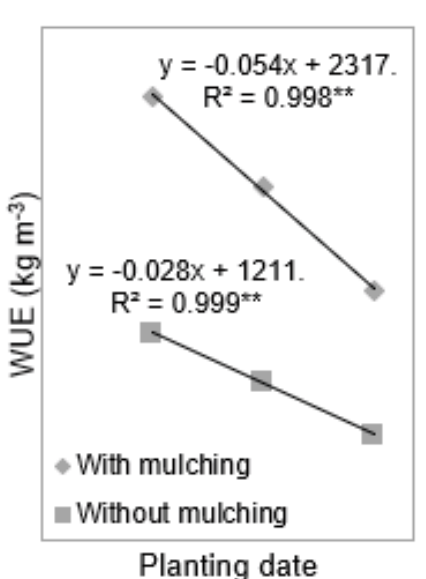

B

Fig. 2: Response of water use efficiency (WUE) to plant. date under (A) the two sizes of onion sets at plant., and (B) the two types of soil covering. Regression eq. were fitted and coefficients of determination $\left(\mathrm{R}^{2}\right)$ were given. ${ }^{* *}=$ significant at $1 \%$ level

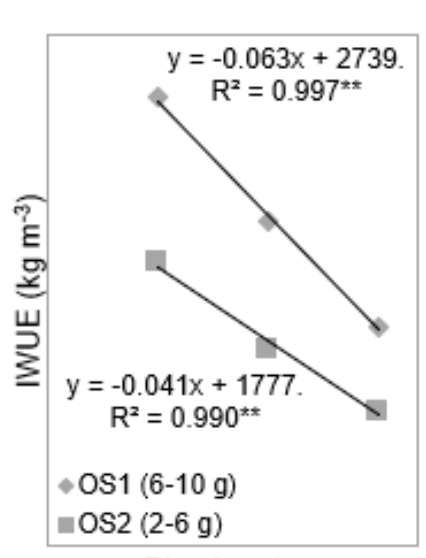

Planting date
A

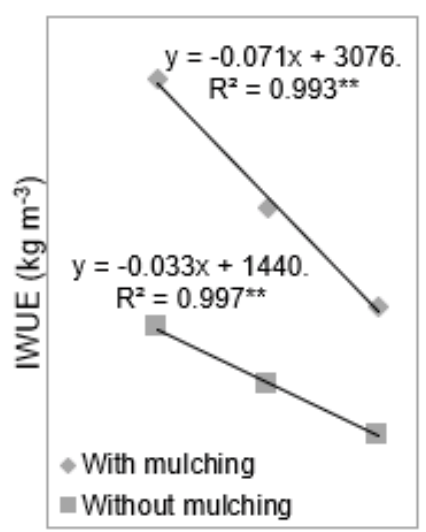

Planting date

Fig. 3: Response of irrigation water use efficiency (IWUE) to planting date under (A) the two sizes of onion sets at planting, and (B) the two types of soil covering. Regression equations were fitted and coefficients of determination $\left(\mathrm{R}^{2}\right)$ were given. ${ }^{* *}=$ significant at $1 \%$ level 
are gradually increased with the early planting date, with significant values of coefficient of determination $\left(\mathrm{R}^{2}\right)$ at the $1 \%$ level, under both sizes of onion sets (Fig. 2A for WUE, and Fig. 3A for IWUE). For each efficiency, both representative lines were not parallel, but did not intersect over the tested period. The slope of fitting line under OS1 was about 1.5 times higher than that under OS2. That is to say that the magnitude of improvements in both WUE and IWUE provoked by the earliness in planting date, could be multiple if larger onion sets are planted. This could illustrate the existence of the planting date $\times$ onion set size interaction $(\mathrm{PD} \times \mathrm{OS})$.

The same trend was detected in the responses of WUE and IWUE to planting date under both types of soil covering (Figs. 2B and 3B, for WUE and IWUE respectively). That is, the degree of enhancements in both WUE and IWUE encouraged by the earliness in planting date could be doubled if mulching is used. The difference in response rate could explain the interaction between planting date and soil cover system $(\mathrm{PD} \times \mathrm{M})$.

On the other hand, the soil cover system $\times$ onion set size interaction effect $(\mathrm{M} \times \mathrm{OS})$ confirmed the important role of mulching in increasing both WUE and IWUE. The highest values of WUE $\left(6.67 \mathrm{~kg} \mathrm{~m}^{-3}\right)$ and IWUE $\left(7.12 \mathrm{~kg} \mathrm{~m}^{-3}\right)$ were obtained when larger onion sets grown under mulching. Significant decreases were observed when smaller sets or/and non-mulching was used. For instance, WUE was reduced by $75 \%$ when smaller sets without mulching was used (Table 3 ).

Such experimental data and developed linear functions could be invested for predicting the targeted values of WUE and IWUE under the dry Mediterranean climate. For example, the best agricultural management suggested to have an efficient use of water (maximum values of both efficiencies) is to plant large onion sets under mulching in February with no-water stress. Under such conditions, WUE and IWUE could be reached 8.37 and $9.57 \mathrm{~kg} \mathrm{~m}^{-3}$, respectively. Furthermore, another important result is that the yield of smaller onion sets could be significantly enhanced when they were planted earlier and if mulching is used. This finding is in agreement with similar results previously obtained on the importance of mulching. For example, Mubarak and Hamdan (2018b) demonstrated that an increase of about $134 \%$ in water use efficiency could be achieved when mulching was used compared with non-mulching conditions, whatever the selected level of irrigation

\section{CONCLUSIONS}

The following conclusions and recommendations can be attained in the studied agro-pedo-climatic context:

Onion crop was found to be responsive to early planting date, larger onion sets at planting, and using straw mulching, so that both bulb shape indicators and the total bulb yield were significantly enhanced, compared with those obtained under the traditional agricultural practices (planting in April without mulching). Both water use efficiency and irrigation water use efficiency were also increased considerably; and the seasonal crop water use and irrigation water amount were found to be obviously decreased.

Results indicated that early planting date and using mulching improved the response of onion crop to smaller onion sets. This could be an appropriate agronomic alternative to meet the ever increasing demand for onions and to save irrigation water in the dry Mediterranean area.

Onion bulb responses were predicted to be increased linearly with the early planting date, but with obvious preferences using mulching and larger onion sets. Both experimental data and developed equations could be invested for predicting onion crop responses under similar environment without conducting any additional trials. Moreover, they could be used as a tool for rational management of onion crop production and limited water resources.

\section{ACKNOWLEDGEMENT}

The author would like to thank the Atomic Energy Commission of Syria for encouragement and financial and technical supports.

\section{REFERENCES}

Abedin, M. J., Rahim, M. A., Islam, K. S., Haider, M. A. (1999). Effect of planting date and bulb size on the yield and quality of onion seed. Bangladesh Journal of Seed Science and Technology, 3, 25-28.

Addai, I. K. (2014). Effects of cultivar and culb size on growth and bulb yield of onion (Allium cepa L.) in the northern region of Ghana. British Journal of Applied Science and Technology, 4(14), 2090-2099. https://doi.org/10.9734/ BJAST/2014/8458

Addai, I. K., Anning, D. K. (2015). Response of onion (Allium cepa L.) to bulb size at planting and NPK 15:15:15 fertilizer application rate in the Guinea Savannah. Journal of Agronomy, 14(4), 304-309. https://doi.org/10.3923/ ja.2015.304.309

Ansari, N., Teixeira da Silva, J., Yazdani, N. (2009). Effect of onion set size and cultivar on production of green bunch 
onion (Allium cepa). Middle Eastern and Russian Journal of Plant Science and Biotechnology. 3, 5-9.

Ashrafuzzaman, M., Nasrul Millat, M., Razi Ismail, M., Uddin, M. K., Shahidullah, S. M., Meon, S. (2009). Paclobutrazol and bulb size effect on onion seed production. International Journal of Agriculture and Biology, 11, 245-250.

Brewster, J. L. (2008). Onions and other vegetable alliums. $2^{\text {nd }}$ Ed., CAB International, Wallingford, United Kingdom. https://doi.org/10.1079/9781845933999.0000

Ceccarelli, S., Grando, S., Baum, M. (2007). Participatory plant breeding in water-limited environments. Experimental Agriculture, 43, 411-435. https://doi.org/10.1017/ S0014479707005327

FAO (2011). Climate change, water and food security. Rome: FAO.

Gimenez, C., Otto, R. F., Castilla, N. (2002). Productivity of leaf and root vegetable crops under direct cover. Scientia Horticulturae, 94, 1-11. https://doi.org/10.1016/S03044238(01)00356-9

Giorgi, F., Lionello, P. (2008). Climate change projections for the Mediterranean region. Global and Planetary Change, 63(2-3), 90-104. https://doi.org/10.1016/j.gloplacha.2007.09.005

Gomez, K. A., Gomez, A. A. (1984). Statistical Procedures for Agricultural Research ( $2^{\text {nd }}$ ed.). New York, NY: John Wiley \& Sons.

Hamma, I. L. (2013). Growth and yield of onion as influenced by planting dates and mulching types in Samaru, Zaria. International Journal of Advance Agricultural Research, 1, 22-26.

Igbadun, H. E., Ramalan, A. A., Oiganji, E. (2012). Effects of regulated irrigation deficit and mulch on yield, water use and crop water productivity of onion in Samaru, Nigeria. Agricultural Water Management, 109, 162-169. https://doi. org/10.1016/j.agwat.2012.03.006

Joffre, R., Rambal, S. (2001). Mediterranean Ecosystems. In: eLS. John Wiley \& Sons Ltd, Chichester. https://doi. org/10.1038/npg.els.0003196

Khaledian, M. R., Mailhol, J. C., Ruelle, P., Mubarak, I., Perret, S. (2010). The impacts of direct seeding into mulch on the energy balance of crop production system in the SE of France. Soil and Tillage Research, 106(2), 218-226. https:// doi.org/10.1016/j.still.2009.10.002

Khaledian, M. R., Mailhol, J. C., Ruelle, P., Mubarak, I., Maraux, F. (2011). Nitrogen balance and irrigation water productivity for corn, sorghum and durum wheat under direct seeding compared with conventional tillage in the Southeastern France. Irrigation Science, 29(2), 413-422. https:// doi.org/10.1007/s00271-010-0250-4

Khokhar, K. M., Hussain, S. I., Mahmood, T., Hidayatullah, M. H., Bhatti, M. H. (2001). Effect of set size on bulb yield, maturity and bolting in local and exotic cultivars of onion during autumn season. Sarhad Journal of Agriculture, 17, 355-358.

Khokhar, K. M. (2014). Flowering and seed development in onion-A Review. Open Access Library Journal, 1: e1049. http://dx.doi.org/10.4236/oalib.1101049

Mohanty, B. K. (2002). Variability, heritability, interrelation- ship and path analysis in onion. Haryana Journal of Horticultural Sciences 31(1-2), 84-87.

Mubarak, I. (2020). Improving water productivity and yield of onion crop by combining early planting and straw mulch under different irrigation levels in dry Mediterranean region. Advances in Horticultural Science, 34(1), 49-60.

Mubarak, I., Hamdan, T. (2018a). Onion crop response to different irrigation and $\mathrm{N}$-fertilizer levels in dry Mediterranean region. Advances in Horticultural Science, 32(4), 495501.

Mubarak, I., Hamdan, T. (2018b). Onion crop response to regulated deficit irrigation under mulching in dry Mediterranean region. Journal Horticultural Research, 26(1), 87-94. https://doi.org/10.2478/johr-2018-0010

Mutetwa, M., Mtaita, T. (2014). Effects of mulching and fertilizer sources on growth and yield of onion. Journal of Global Innovation in Agricultural and Social Sciences, 3, 102-106. https://doi.org/10.17957/JGIASS/2.3.561

Onofri, A. (2007). Routine statistical analyses of field experiments by using an Excel extension. National Conference Italian Biometric Society. Proceeding $6^{\text {th }}$ (Pisa). In: "La statistica nelle scienze della vita e dellambiente"; 20-22, 93-96.

Polade, S. D., Pierce, D. W., Cayan, D. R., Gershunov, A., Dettinger, M. D. (2014). The key role of dry days in changing regional climate and precipitation regimes. Scientific Reports, 4, 43-64. https://doi.org/10.1038/srep04364

Ragab, R., Prudhomme, C. (2002). Climate change and water resources management in arid and semi arid regions: prospective and challenges for the 21 st century. Biosystems Engineering, 81, 3-34. https://doi.org/10.1006/bioe.2001.0013

Rohini, N., Paramaguru, P. (2016). Seasons' influence on bulb, seed yield and quality of aggregatum onion. International Journal of Farm Sciences, 6(1), 174-183.

Singh, S. R., Sachan, B. P. (1999). Interaction of bulb size and spacing on seed yield and yield attributing trait of onion (Allim cepa L.) cv. Kalyanpur Round Red. Scientia Horticulturae, 6, 125-128.

Somot, S., Sevault, F., Deque, M., Crepon, M. (2008). $21^{\text {st }}$ century climate change scenario for the Mediterranean using a coupled atmosphere-ocean regional climate model. Global Planet Change, 63(2-3), 112-126. https://doi. org/10.1016/j.gloplacha.2007.10.003

Turner, N.C. (2004). Sustainable production of crops and pastures under drought in a Mediterranean environment. Annals of Applied Biology, 144, 139-147. https://doi. org/10.1111/j.1744-7348.2004.tb00327.x

Vavrina, C. S., Roka, F. M. (2000). Comparison of plastic mulch and bareground production and economics for short-day onions in a semitropical environment. HortTechnology, 10, 326-330. https://doi.org/10.21273/HORTTECH.10.2.326

Zinkernagela, J., Schmidta, N., Kahlen, K. (2015). Changing thermal growing season and climatic water balance affect irrigation and cultivation period of vegetables. Procedia Environmental Sciences, 29, 51-52. https://doi. org/10.1016/j.proenv.2015.07.153 